\title{
Precipitation intensity-duration-frequency curves for central Belgium with an ensemble of EURO-CORDEX simulations, and associated uncertainties
}

\author{
Parisa Hosseinzadehtalaei ${ }^{1, *}$, Hossein Tabari ${ }^{1}$ and Patrick Willems ${ }^{1,2}$
}

1) Hydraulics Division, Department of Civil Engineering, KU Leuven, Kasteelpark Arenberg 40, BE3001 Leuven, Belgium.

2) Department of Hydrology and Hydraulic Engineering, Vrije Universiteit Brussel, Belgium.

*Email: parisa.hosseinzadehtalaei@kuleuven.be; parisa.talaee@gmail.com, Tel: +32 16377007, Fax: +32 16321989 .

\begin{abstract}
An ensemble of 88 regional climate model (RCM) simulations at $0.11^{\circ}$ and $0.44^{\circ}$ spatial resolutions from the EURO-CORDEX project is analyzed for central Belgium to investigate the projected impact of climate change on precipitation intensity-duration-frequency (IDF) relationships and extreme precipitation quantiles typically used in water engineering designs. The rate of uncertainty arising from the choice of RCM, driving GCM, and radiative concentration pathway (RCP4.5 \& RCP8.5) is quantified using a variance decomposition technique after reconstruction of missing data in GCM $\times$ RCM combinations. A comparative analysis between the historical simulations of the EUROCORDEX $0.11^{\circ}$ and $0.44^{\circ}$ RCMs shows higher precipitation intensities by the finer resolution runs, leading to a larger overestimation of the observations-based IDFs by the $0.11^{\circ}$ runs. The results reveal that making a temporal stationarity assumption for the climate system may lead to underestimation of precipitation quantiles up to $70 \%$ by the end of this century. This projected increase is generally larger for the $0.11^{\circ} \mathrm{RCMs}$ compared with the $0.44^{\circ} \mathrm{RCMs}$. The relative changes in extreme precipitation do depend on return period and duration, indicating an amplification for larger return periods and for smaller durations. The variance decomposition approach generally identifies RCM as the most dominant component of uncertainty in changes of more extreme precipitation (return period of 10 years) for both $0.11^{\circ}$ and $0.44^{\circ}$ resolutions, followed by GCM and RCP scenario. The uncertainties
\end{abstract}


associated with cross-contributions of RCMs, GCMs, and RCPs play a non-negligible role in the associated uncertainties of the changes.

Keywords: Extreme precipitation, Future IDF curves, Climate model resolution, Quantile perturbation downscaling, Variance decomposition, Uncertainty analysis

\section{Introduction}

More frequent and intense occurrence of extreme precipitation events by the end of the 21 s century is expected under climate change conditions (Willems et al., 2012a; Sunyer et al., 2012; IPCC, 2013; Willems, 2013; Liew et al., 2014; Tabari et al., 2015; Pohl et al., 2017). This leads to an increase in the flood hazard with adverse impact on existing water infrastructure, resulting in human harm and economic losses. Urban water infrastructure (i.e., different components of storm water management systems such as sewer conduits, storm water management ponds, retention/detention basins) and flood control structures (e.g., dikes, dams) are typically designed based on the properties of extreme precipitation in the form of intensity-duration-frequency (IDF) curves (Peck et al., 2012; Hosseinzadehtalaei et al., 2017). The IDF curves quantify the frequency of occurrence of a storm with a specific intensity at different durations and its application for developing design standards has been common practice for many decades (e.g., Willems et al., 2012b). The IDF curves are currently based on historical precipitation statistics with a temporal stationarity assumption for these statistics. However, climate change will change the properties of extreme precipitation and violates this assumption. Therefore, the current design standards based on IDF curves need to be revised and the expected changes in precipitation properties must be incorporated for the future infrastructure designs.

Global climate models (GCMs) have been considered as initial and proper tools for climate change evaluation and future climate projections (Katragkou et al., 2015; Almazrouia et al., 2016; Das et al., 2016; Hosseinzadehtalei et al., 2016; Karandish et al., 2016). However, they have a coarse spatial resolution (mainly ranging between 100 and $500 \mathrm{~km}$ ) at which capturing the detail of regional/local climate change is not competently possible (Endris et al., 2013; Tabari et al., 2016; Saeed et al., 2017). Hence, dynamically downscaled climate models to finer spatial scale (regional climate models: 
RCMs) have been developed to provide climate change information suitable for impact studies (Alfieri et al., 2015). For the European area, the PRUDENCE (Christensen et al., 2007; Jacob et al., 2007) and ENSEMBLES (Van der Linden and Mitchell, 2009) projects have provided RCM simulations nested in the Coupled Model Intercomparison Project- Phase 3 (CMIP3) GCMs on gridsizes down to $0.44^{\circ}$ and $0.22^{\circ}$, respectively. Recently, a high resolution European RCM ensemble within the World Climate Research Program Coordinate Regional Downscaling Experiment (EUROCORDEX) has been established using the CMIP5 GCMs as driving models for RCMs with $0.44^{\circ}$ and $0.11^{\circ}$ spatial resolutions.

Regional climate models, driving GCMs, different greenhouse gas emission scenarios and their interactions as well as internal variability add several sources and rates of uncertainty to extreme precipitation projections and construction of future IDF curves. Quantification of the sources and rates of the uncertainties associated with the future extreme precipitation and IDF curves would be potentially helpful for climate change adaptation strategies and risk-based decision making. Accordingly, a number of studies have investigated the uncertainty of hydrological design parameters in a changing climate (Thorne, 2011; Knutti and Sedláček, 2013; Katz et al., 2013; Refsgaard et al., 2013; Rana et al., 2014; Sarr et al., 2015; Hosseinzadehtalei et al., 2017). The impact of climate change on IDF relationships has also been studied (Mailhot et al., 2007; Madsen et al., 2009; Willems et al., 2012; Yilmaz et al., 2014; Kim et al., 2015); however, these studies have mostly focused on the impact of climate change on the IDF curves without taking into account the associated uncertainty. Hence, in this study, the total uncertainty in the derivation of future changes in IDF relationships and the relative contribution of GCMs, RCMs and greenhouse gas scenarios in the form of Radiative Concentration Pathways (RCPs) is investigated using a variance decomposition technique. Also, the influence of the RCM spatial resolution is studied. The more specific research questions considered are:

(i) How will the IDF curves change under climate change based on the EURO-CORDEX RCM projections for the end of the 21 st century?

(ii) How large is the relative uncertainty of GCMs, RCMs and RCPs to the total uncertainty of climate change impact on extreme precipitation for different durations and return 
periods (i.e., future IDF relationships) using outputs from an ensemble of the EUROCORDEX RCMs?

(iii) Does decreasing the horizontal grid spacing in the EURO-CORDEX RCMs from $0.44^{\circ}$ to $0.11^{\circ}$ improve their extreme precipitation simulations?

To answer these questions, an ensemble of the EURO-CORDEX RCMs for $0.11^{\circ}$ and $0.44^{\circ}$ spatial resolutions and for the future RCP4.5 and RCP 8.5 scenarios is analyzed for central Belgium.

\section{Methodology and data}

\subsection{Model data}

For this study, we use daily precipitation data from eight EURO-CORDEX RCMs. The models are RCA4, RACMO22E, HIRHAM5, CCLM4-8-17, WRF331F, REMO2009, ALADIN52 and RegCM4-3 whose data are publicly available through the Earth System Grid Federation server (https://esgf-data.dkrz.de/search/cordex-dkrz/). These high-resolution RCMs are forced by 10 CMIP5 GCMs. Daily precipitation from historical simulations from 1961 to 1990 and climate projections from 2071 to 2100 at $0.11^{\circ}$ and $0.44^{\circ}$ horizontal resolutions are obtained from the EURO-CORDEX database for the model gridcell covering central Belgium. Simulations from a matrix of $3 \times 3$ EUROCORDEX model gridcells centered over Uccle station (main meteorological station of Belgium) are analyzed. A comparison between the extreme precipitation simulations from the central gridcell (closest grid to Uccle station) and its eight neighboring cells assure us that using the simulations from only the central gridcell can accurately simulate local climate information (examples are shown in Fig. 1). Nearest neighbor method is used to get the data from the closest model gridcell (with dimensions $0.44^{\circ} \times 0.44^{\circ}$ and $0.11^{\circ} \times 0.11^{\circ}$ ) to the Uccle station location.

< Figure 1 here please >

It should be noted that the control runs of the RCA4 RCM for $0.11^{\circ}$ resolution and the WRF331F RCM for both $0.11^{\circ}$ and $0.44^{\circ}$ resolutions do not have data for the 1960 s, hence, the period 1971 2000 is used as their control period. This difference in the time period poses no limitation to the 
analysis as a 30-year RCM integration just represents one possible 30-year realization of the climate and not the actual sequence of weather events (Maraun et al., 2010). The changes reported in this paper are for a 110-year period (from 1961-1990 to 2071-2100) for all the RCMs except for WRF331F and RCA4 RCMs for which the changes correspond to a period of 100 years (from 19712000 till 2071-2100). To make the changes obtained from WRF331F and RCA4 RCMs consistent with those from the other RCMs, the changes from these two models are modified by applying a factor $110 / 100$, hence assuming a linear change in time.

For the future climate, the projections of the EURO-CORDEX RCMs are available mainly for the Radiative Concentration Pathways RCP4.5 and RCP8.5, which correspond respectively to mid and high concentration scenarios of greenhouse gases in the atmosphere. In total, $88 \mathrm{RCM}$ simulations including 42 runs for $0.11^{\circ}$ ensemble and 46 runs for $0.44^{\circ}$ ensemble are analyzed in this study.

\subsection{Observation data}

To evaluate the model simulations for daily precipitation, the observations for the period 1961-1990 at Uccle (Brussels) station $\left(4.4^{\circ} \mathrm{E}\right.$ and $\left.50.8^{\circ} \mathrm{N}\right)$ operated by the Royal Meteorological Institute of Belgium are used since this station has high quality, long rainfall records. One might argue that the characteristics of the precipitation distribution observed in Uccle may not be captured by the RCMs in this exact location. To address this issue, as there is no raingauge with high quality and long precipitation data in the vicinity, the RCM simulations over a larger domain of nine gridcells $(3 \times 3$ matrix) are compared for possible different extreme precipitation pattern in the neighboring gridcells (Fig. 1). The results show a consistent pattern over the larger domain $\left(1.32^{\circ} \times 1.32^{\circ}\right.$ for the $0.44^{\circ}$ runs and $0.33^{\circ} \times 0.33^{\circ}$ for the $0.11^{\circ}$ runs). Next to the Uccle station observations, gridded daily precipitation values from the E-OBS (v12.0, Haylock et al., 2008) for the period 1961-1990, dataset from the $\begin{array}{llll}\text { European } & \text { Climate } & \text { Assessment } & \text { and }\end{array}$ http://www.ecad.eu/download/ensembles/download.php), for $0.5^{\circ}$ and $0.25^{\circ}$ spatial resolutions are used. The E-OBS data for the closest gridcell to Uccle station are derived using the nearest neighbor method. 


\subsection{Development of IDF curves for the current and future climates}

To construct the IDF curves, statistical extreme value analysis is required. The most popular practice in extreme value analysis is to assume that extreme values belong to the same population and follow the same type of distribution. However, single-component distributions may not work well for the upper tail of the distribution when extreme precipitation arises from two different physical mechanisms: predominantly stratiform and convective storm types. Hence, a two-component distribution is needed to properly fit precipitation extremes resulting from both micro-scale thunderstorms (convective rain cells) and macro-scale frontal/cyclonic storms (Rulfová et al., 2016; Yan et al., 2017). For Belgium, IDF curves have been set up by Willems (2000), based on Peak-OverThreshold (POT) extreme value statistics after calibration of a two-component exponential distribution. The distribution was calibrated by weighted regression in the exponential quantile plot to the POT extremes extracted from the full time series. To have a sufficiently large set of extremes, a low threshold of $0.1 \mathrm{~mm}$ is selected for the POT. The same procedure is used in this study to develop IDF curves for the simulations of the EURO-CORDEX RCMs for 1-month, 1-year and 10-year return periods. Although very low return periods are not important in design applications, the precipitation intensity of 1-month return period is analyzed to compare the climate change impact on more extreme precipitation with that on less extreme precipitation. Following Willems (2000, 2013), in this study, the return period $T$ for independent precipitation extremes $x$ obtained from the POT method is defined for the two-component exponential distribution as:

$T=\frac{n}{t\left(p_{a}\left(1-G_{a}(x)\right)+\left(1-p_{a}\right)\left(1-G_{b}(x)\right)\right)}$

in which $G_{a}(x)$ and $G_{b}(x)$ are two different exponential distribution functions for subpopulations $a$ and $b$ that are presumed to be associated with convective and frontal types of rain storms (Willems, 2000):

$G_{a}(x)=1-\exp \left(-\frac{x-x_{t}}{\beta_{a}}\right)$

$G_{b}(x)=1-\exp \left(-\frac{x-x_{t}}{\beta_{b}}\right)$ 
where $n$ is the total length of the precipitation time series (30 years in our case), $t$ is the observed order of the threshold level above which the distribution is considered, $\beta$ is the distribution parameter, $x_{t}$ is the optimal threshold and $p_{a}$ represents the proportion of population $a$.

The IDF curves are developed in this study for a broad range of durations from 1 up to 30 days. The studied range of durations depends on the application. The concentration time (travel time of water from the most remote point in a watershed to the outlet) or response time to rainfall of the system under study, which can be a sewer system, river or catchment runoff, define the largest duration relevant for the application. The shorter durations of 1 or few days are representative for the concentration/recession time of the runoff flows in Belgian catchments. The longer durations up to 30 days are of relevance for water availability studies or soil saturation analysis. By considering the wide range of durations from 1 to 30 days, we moreover compare the difference in climate change impact on precipitation between small and large time scales.

The IDF curves for the future climate are developed on the basis of a quantile perturbation downscaling approach (Willems, 2013) by applying change factors to the extreme precipitation statistics from station observations for each return period and duration. The change factor is defined as the ratio between the precipitation values for the scenario period and the corresponding values in the control period. In the quantile perturbation approach, given that the relative changes are applied to the observations based IDF curves, bias correction is intrinsically considered. In fact, this type of methods assumes that the bias under future climate conditions is identical to the bias in current climate conditions. Figure 2 summarizes the applied methodology to develop future IDF curves and to analyze the related uncertainties.

\footnotetext{
$<$ Figure 2 here please >
}

\subsection{Uncertainty analysis}

The total ensemble uncertainty for climate change signals of extreme precipitation is split in the variance contributions using a variance decomposition approach. The contributions of the uncertainties in the GCMs, RCMs and RCPs to the overall uncertainty are investigated for each return 
period and duration for both $\mathrm{RCM}$ resolutions $\left(0.11^{\circ}\right.$ and $\left.0.44^{\circ}\right)$. The total variance can be split into the above three contributors as well as the interactions among them using the following relationship:

$\operatorname{Var}(T)=\operatorname{Var}(R)+\operatorname{Var}(G)+\operatorname{Var}(S)+\operatorname{Var}(R G)+\operatorname{Var}(R S)+\operatorname{Var}(G S)+\operatorname{Var}(R G S)$

where $\operatorname{Var}(T)$ is the total variance, $\operatorname{Var}(R)$ is the variance associated with the ensemble of RCMs, similarly $\operatorname{Var}(G)$ for the ensemble of GCMs, and $\operatorname{Var}(S)$ for the RCPs and $\operatorname{Var}(R G), \operatorname{Var}(R S)$, $\operatorname{Var}(G S)$ and $\operatorname{Var}(R G S)$ are the variance associated with the interactions between the three contributors. For instance, the full contribution of GCM uncertainty $\left(\operatorname{Var}_{f}(G)\right)$ to $\operatorname{Var}(T)$ can be obtained by:

$\operatorname{Var}_{f}(G)=\operatorname{Var}(G)+\operatorname{Var}(R G)+\operatorname{Var}(G S)+\operatorname{Var}(R G S)$

In a similar procedure, the full contributions of RCM and RCP uncertainties are computed. The method was described in detail in Déqué et al. (2007, 2012).

The variance decomposition would be a simple exercise when there are no missing data (gaps) in the RCM-GCM matrix (Tables 1 and 2). Tables 1 and 2 display which CMIP5 GCM is driving which EURO-CORDEX RCM. The missing RCM-GCM combinations make it an unbalanced matrix. For example, for $0.11^{\circ}$ resolution (Table 1) three RCMs are forced by the HadGEM2-ES (r1i1p1) GCM, while only one RCM is driven by the EC-EARTH (r1ilp1) GCM. This leads to overweighting of the HadGEM2-ES (r1i1p1) GCM in comparison to the EC-EARTH (r1i1p1) GCM. A solution to avoid this biased ensemble estimation would be to reconstruct missing combinations by means of statistical techniques such as principal component analysis (PCA). Due to the existence of many missing combinations in our case, PCA method can produce strange artifacts. Déqué et al. (2007, 2012), therefore, developed an alternative method to estimate change factors for missing combinations. As a simple example to explain how the method works, let us consider a missing combination in the RCMGCM matrix that is related to RCM I forced by GCM II. The change factor for this missing combination is estimated by assuming an additive contribution of GCM II and RCM $I$. It means the mean anomaly of the change factors derived from the GCM II-driven pairs from the overall mean of the change factors (considering all RCMs $\times$ GCMs) and the mean anomaly of the change factors derived from the RCM I-driven pairs from the overall mean are added to the overall mean to estimate 
the missing value. The method has been applied in several European studies to complete the set of simulations by the PRUDENCE and ENSEMBLES RCMs (Vidal and Wade, 2008; Sunyer et al., 2015). In our application, three instead of two uncertainty contributors (GCM, RCM, RCP) are considered. The small sample size of EURO-CORDEX RCMs is a limitation for the robustness of the uncertainty assessment.

$<$ Tables 1 and 2 here please $>$

\section{Results and discussion}

The IDF curves for the historical and future periods are created for five durations (1-, 5-, 10-, 15- and 30-day) and three return periods (1-month, 1-year, 10-year) and the associated uncertainty was quantified. The results are presented in the subsequent sections.

\subsection{Current climate IDF curves}

Figure 3 shows the IDF curves of the historical period for the EURO-CORDEX $0.11^{\circ}$ and $0.44^{\circ}$ RCMs for different durations and return periods. The performance evaluation of IDF curves is done by comparing the simulation results with the Uccle observations. We also compare the EUROCORDEX results with the E-OBS gridded observations with similar grid size (E-OBS data for exactly the same grid size as that of the EURO-CORDEX RCMs are not available). Since gridded (spatially averaged) precipitation leads to lower values in comparison to station precipitation values (Chen and Knutson, 2008; Hofstra et al., 2010; Sunyer et al., 2013), the higher values of the current IDF curves derived from the EURO-CORDEX RCMs compared with the station observations should be clearly interpreted as "overestimation". Figure 3 shows that for the shorter durations the IDF curves for the Uccle station and E-OBS do not show a strong agreement especially for $\mathrm{T}=10$ years for which the spread is the largest. Nonetheless, for intermediate and long durations, there is a strong agreement between the IDF curves from the two observation sources. For the spatial resolution of $0.11^{\circ}$ using 14 RCM runs, it can be seen in Fig. 3a that extreme precipitation intensity for 1-month and 1-year return periods is mostly overestimated compared to the Uccle station and E-OBS observations. For a 10-year 
return period with daily duration, the $0.11^{\circ} \mathrm{RCMs}$ overestimate the precipitation intensity with respect to the E-OBS observations and both overestimations and underestimations are observed in comparison with the Uccle station observations. The range of IDF curves from the ensemble of simulations at $0.11^{\circ}$ resolution encompasses the IDF curve derived from the observations, both for the Uccle station measurements and E-OBS in the surrounding area. For the $0.44^{\circ} \mathrm{RCMs}$ (16 runs), the spread of the IDFs from the model ensemble is quite large, especially for the 10-year and 1-month return periods, which indicate a high level of uncertainty, but centered around the IDFs from the observations (Fig. 3b). The strongest agreement (the least spread) for the model ensemble is for $\mathrm{T}=1$ year.

< Figure 3 here please >

A comparison between 9 simulations at $0.11^{\circ}$ and $0.44^{\circ}$ resolutions with identical combination of GCMs and RCMs indicates that the precipitation intensity simulated by the $0.11^{\circ}$ runs is mostly higher than that of the $0.44^{\circ}$ runs (Fig. 3c). Precipitation intensity simulated by the RCA4 (nested in CNRM-CM5, EC-EARTH, IPSL-CM5A-MR, MPI-ESM-LR and HadGEM2-ES) and HIRHAM5 (nested in EC-EARTH) RCMs of $0.11^{\circ}$ resolution is higher than that of $0.44^{\circ}$ resolution, while for two RCM runs (CCLM4-8-17 nested in MPI-ESM-LR and RACMO22E nested in EC-EARTH) an opposite pattern is seen: lower intensities for the $0.11^{\circ}$ runs. The WRF331F RCM (nested in the IPSLCM5A-MR GCM) shows a mixed behavior. A comparison between the median of the EUROCORDEX $0.44^{\circ}$ and $0.11^{\circ}$ simulations shows a larger difference between the IDF curves of these two datasets for more extreme precipitation (Table 3). The difference goes up to $30 \%$ for daily precipitation of 10-year return period. In general, more intense precipitation is simulated by the $0.11^{\circ}$ simulations for all durations and return periods except for 15- and 30-day precipitation of 1-month return period.

It can be generally inferred from the model validation analysis that the IDF curves derived from the EURO-CORDEX simulations have a large spread around the IDFs from observations. This indicates a high level of uncertainty in these simulations which needs to be quantified. 
$<$ Table 3 here please >

\subsection{Future climate IDF curves}

Figure 4 shows the change factors $(\mathrm{CFs})$ of extreme precipitation for the $0.11^{\circ}$ and $0.44^{\circ} \mathrm{RCMs}$. According to the boxplots, the future extreme precipitation quantiles will increase for most durations and return periods based on the median of the change factors. The decrease $(\mathrm{CF}<1)$ is observed for less extreme precipitation (i.e., smaller return periods and larger durations). For the daily time scale, the 10-year precipitation intensity for RCP8.5 and RCP4.5 can increase up to about $70 \%$ (95th percentile of $\mathrm{CF}=1.66$ ) and $50 \%$ (95th percentile of $\mathrm{CF}=1.48$ ) for the future, respectively (Fig. 4a and b). Considering the RCP8.5 scenario (Figs. 4b, d and f), the amount of increase in extreme precipitation is smaller for larger durations. However, such clear pattern is not detectable for RCP4.5, probably because the climate change signal on precipitation is less strong. Further, by increasing the return period, the changes in precipitation tend to intensify. Comparing the results for RCP4.5 and RCP8.5, as expected from the literature (e.g., Toreti et al., 2013; Donat et al., 2017), RCP8.5 mostly indicates larger changes in precipitation intensity. Generally, the results show that the projected changes in extreme precipitation intensity do depend on return period, duration and the RCP scenario.

< Figure 4 here please >

A comparison between the change factors of precipitation intensity for the $0.11^{\circ}$ and $0.44^{\circ}$ runs with identical combination of GCMs and RCMs is shown in Fig. 5. Taking the 95th percentile of the change factors, the $0.11^{\circ} \mathrm{RCMs}$ project a larger future change compared with the $0.44^{\circ} \mathrm{RCMs}$ for both RCP4.5 and RCP8.5, while such pattern is not seen for the 1-year return period considering the median of the change factors. Also, the largest difference between change factor distributions for the ensemble of simulations is for the largest return period considered ( $\mathrm{T}=10$ years).

\footnotetext{
$<$ Figure 5 here please >
} 
The projected IDF curves for the future based on all $0.11^{\circ}$ and $0.44^{\circ}$ RCMs are shown in Figs. 6a and $b$, respectively. Both ensembles of RCMs show a general tendency to increase precipitation intensities for different return periods and durations, locating the future IDF curves higher than the observed ones from Uccle station for the present climate. This means that hydraulic structures designed based on the current climate IDF relationships may not be suitable for the future intensified precipitation extremes. When the future IDF curves derived from the $0.11^{\circ} \mathrm{RCMs}$ are compared with those from the $0.44^{\circ} \mathrm{RCMs}$ (Figs. 6c and d), the $0.11^{\circ} \mathrm{RCM}$ projections for more extreme precipitation further emphasize the necessity to revise the existing IDF curves. Main question here is whether further increase of the climate model resolution would further increase the extreme precipitation changes; see also the debate by Willems et al. (2012a), Arnbjerg-Nielsen et al. (2013), Casanueva et al. (2016), Lind et al. (2016), Prein et al. (2016), Rummukainen (2016) and Tabari et al. (2016) on this.

$<$ Figure 6 here please >

\subsection{Uncertainty analysis of projected changes in IDF statistics}

Since assessment of uncertainty in climate change projections is essential for any application, quantification of the different sources of uncertainty in the projected changes in extreme precipitation quantiles is intended. In the following, the uncertainty of RCMs, driving GCMs, RCPs and the interaction between them are presented. An unbiased uncertainty analysis is performed once a balanced matrix of $\mathrm{RCM} \times \mathrm{GCM}$ is created by filling the missing combinations.

Figure 7 shows the respective uncertainty of RCMs, GCMs and RCPs for different return periods (1-month, 1-year, 10-year) and durations (1-, 5-, 10-, 15- and 30-day) for the RCMs of $0.11^{\circ}$ resolution. Based on the results, the uncertainty in the RCM results is in 53\% of the cases larger than the other uncertainty components. When comparing RCM and GCM uncertainties, the RCM uncertainty in $80 \%$ of the cases is larger than the GCM uncertainty. In the case of 10-day duration of 1- and 10-year return periods and 15-day duration of 1-year return period, GCMs produce larger uncertainty compared to RCMs. This is probably due to their coarse resolution, which induces a 
higher bias to the more extreme precipitation intensities. The RCP related uncertainty differs from $3.1 \%$ for a 10 -day duration and a 10 -year return period to $29.1 \%$ for a 1 -day duration and a 1 -month return period. In general, the choice of RCM is the dominant source of uncertainty for shorter durations of 1- and 5-day precipitation, while there is no clear pattern for larger durations.

$<$ Figure 7 here please >

In the case of the RCMs of $0.44^{\circ}$ resolution (Fig. 8), the largest uncertainty for $60 \%$ of the durations and return periods comes from the RCMs. For the rest of the cases (1- and 5-day durations of 1-month and 1-year return periods, 10-day duration of 1-month return period and 30-day duration of 1-year return period), the GCM source shows larger uncertainty. For 1-, 5- and 10-day durations, the amount of GCM uncertainty decreases with increasing return period. In the case of RCM uncertainty, the uncertainty increases with return period for 1- and 5-day durations. It's worthwhile to note that strong uncertainty in the RCP component hardly occurs for the $0.44^{\circ} \mathrm{RCMs}$, similar to the $0.11^{\circ}$ RCMs. This is partly due to the unavailability of precipitation data for RCP2.6 and RCP6.0 especially for the former RCP in the EURO-CORDEX RCM dataset, which leads to an underestimation of the RCP variance and the related uncertainty.

< Figure 8 here please >

The overall results for both ensembles of RCMs indicate that RCMs play the main role in the uncertainty of the projected changes in more extreme precipitation for construction of IDF curves. For less extreme precipitation, the dominate source varies very much according to duration. The RCM uncertainty is because of different techniques used by the models to discretize the differential equations and to represent subgrid physical processes (Déqué et al., 2012).

For some cases, especially for the $0.11^{\circ} \mathrm{RCMs}$, the uncertainty analysis indicates small contributions of RCMs, GCMs and RCPs and large cross-contribution. It can be ascribable by internal variability. According to Mearns et al. (2013), large values of cross term compared to other 
components, can be related to (i) large internal variability of the climate system or (ii) similar response of RCM-GCM combinations to the climate change. To investigate the reason for the large cross-contribution, uncertainty rates for two cases (daily precipitation with $\mathrm{T}=10$ years and monthly precipitation with $\mathrm{T}=1$ month) with high amount of cross uncertainty (HCU) are compared with those for two cases (daily precipitation with $\mathrm{T}=1$ month and 10 -daily precipitation with $\mathrm{T}=1$ year) with low amount of cross uncertainty (LCU) (Fig. 9). From a mathematical point of view, the value for the cross-contribution uncertainty is high when the values for the other three components are low. The analysis shows that the uncertainty rates of the GCM, RCM and RCP components in the HCU cases are not lower than those for the LCU cases. Hence, HCU is because of the large rate of the total uncertainty rather than the small rates of the other components, suggesting the large internal variability as the reason. Generally, the interactions between the uncertainty sources for the $0.11^{\circ}$ RCMs account for about $6 \%-65 \%$ of the total ensemble uncertainty, which is larger than the contribution of the interaction term for the $0.44^{\circ} \mathrm{RCMs}$ ranging between $6 \%$ and $22 \%$. This highlights the importance of considering the interactions among individual uncertainty sources especially for finer resolution RCMs: neglecting the interaction term would lead to overestimation of the uncertainty rates associated to individual sources.

\footnotetext{
$<$ Figure 9 here please >
}

As the results of the variance decomposition analysis may be influenced by the method used to fill the matrix (Sunyer et al., 2015), another method (linear equation system: LES) is also used to reconstruct the missing combinations in the RCM-GCM matrix. The LES method is based on solving the linear equation system of the ANOVA design matrix which differs from the iterative linear reconstruction method developed by Déqué et al., (2007). The uncertainty analysis (not shown) by the variance decomposition approach after reconstructing the missing combinations by the LES method shows very similar results to those obtained from the iterative linear reconstruction method.

Next to the uncertainty analysis of changes in extreme precipitation after reconstructing missing values in the $\mathrm{RCM} \times \mathrm{GCM}$ combinations, uncertainty analysis is also performed using original data 
(without reconstruction) to find out the bias involved with the uncertainty results in the latter analysis (Figs. S1 and S2). The results of this analysis for both the $0.11^{\circ}$ and $0.44^{\circ} \mathrm{RCMs}$ attributes the largest uncertainty to the GCMs. On average, the uncertainty rate of the GCM component for the $0.44^{\circ}$ $\left(0.11^{\circ}\right) \mathrm{RCMs}$ increases from $34 \%(24 \%)$ in the constructed missing value case to $48 \%(31 \%)$ in the unconstructed case. Generally, the results show that the biases in using an unbalanced $\mathrm{RCM} \times \mathrm{GCM}$ matrix can be quite large, leading to a misconclusion for uncertainty analysis.

\section{Conclusions}

This study aims to develop precipitation IDF curves for central Belgium using new high resolution simulations from the EURO-CORDEX for two radiative concentration pathways (RCP 4.5 \& RCP 8.5) and to assess the possible impact of climate change on the IDF curves. A comparative assessment between the RCMs of $0.11^{\circ}$ and $0.44^{\circ}$ grid spacing along with an analysis of the associated uncertainties are performed for precipitation of 1-month, 1-year and 10-year return periods and durations ranging between 1 and 30 days. Based on the validation results, the $0.11^{\circ}$ RCMs generally overestimate historical precipitation intensities compared to the Uccle station and E-OBS observations, while the simulations for the $0.44^{\circ} \mathrm{RCMs}$ lie mostly between the Uccle station and EOBS observations, implying higher precipitation intensities by higher resolution runs. Similarly, the climate projection ensemble with RCMs at $0.11^{\circ}$ resolution shows a larger increase in precipitation than with RCMs at $0.44^{\circ}$ resolution for the end of the 21 st century, at the region of interest in central Belgium. In the case of the daily duration, based on the $0.11^{\circ} \mathrm{RCMs}$ the 10 -year precipitation intensity for RCP4.5 and RCP8.5 can increase up to around 50\% and 70\% respectively, whereas smaller increases are projected for the $0.44^{\circ}$ RCMs: $25 \%$ and $50 \%$ for RCP4.5 and RCP8.5, respectively.

The uncertainty in the extreme precipitation changes is, however, large in all cases. The highest contribution to this uncertainty for more extreme precipitation is the RCM uncertainty. For the $0.11^{\circ}$ ensemble, the choice of RCM roughly contributes between $17 \%$ and $50 \%$ to the total uncertainty, while the RCM contribution for the $0.44^{\circ}$ ensemble peaks up to $69 \%$. This means that one can give slightly higher trust to the higher changes obtained from the higher resolution RCMs than from the 
coarser models. The uncertainty analysis also reveals a greater role of the boundary forcing (i.e., GCM) compared to the future greenhouse gas scenario (i.e., RCP). The uncertainties associated with cross-contributions of RCMs, GCMs and RCPs are also of the same order of magnitude or higher than the primary source of uncertainty, for the majority of cases considered.

\section{Acknowledgements}

The authors acknowledge the climate modeling centers for the EURO-CORDEX simulations and the free availability of the data. We are grateful to the European Climate Assessment and Data for the EOBS data. Two anonymous reviewers are thanked for their insightful and constructive comments and suggestions that greatly improved the quality of the manuscript. The work described in this paper has received funding for projects for the Belgian Science Policy Office (CORDEX.be), the Flemish Environment Agency, and the European Union's Horizon 2020 research and innovation programmes under grant agreement No 700699, project BRIGAID (BRIdges the GAp for Innovations in Disaster resilience), and grant agreement No 730004, project PUCS (Pan-European Urban Climate Service).

\section{References}

Alfieri, L., Burek, P., Feyen, L., Forzieri, G., 2015. Global warming increases the frequency of river floods in Europe. Hydrol. Earth Syst. Sci. 19, 2247-2260. http://dx.doi.org/10.5194/hess-19-22472015.

Almazroui, M., Saeed, F., Islam, M.N., Alkhalaf, A.K., 2016. Assessing the robustness and uncertainties of projected changes in temperature and precipitation in AR4 Global Climate Models over the Arabian Peninsula. Atmos. Res. 182, 163-175. http://dx.doi.org/10.1016/j.atmosres.2017.05.005.

Arnbjerg-Nielsen, K., Willems, P., Olsson, J., Beecham, S., Pathirana, A., Bülow Gregersen, I., Madsen, H., Nguyen, V-T-V., 2013. Impacts of climate change on rainfall extremes and urban drainage systems: a review. J. Wat Sci Tech. 68(1), 16-28. http://dx.doi.org/10.2166/wst.2013.251.

Casanueva, A., Kotlarski, S., Herrera, S., Fernández, J., Gutiérrez, J.M., Boberg, F., Colette, A., Christensen, O.B., Goergen, K., Jacob, D., Keuler, K., Nikulin, G., Teichmann, C., Vautard, R., 
2016. Daily precipitation statistics in a EUROCORDEX RCM ensemble: added value of raw and bias-corrected high-resolution simulations. Clim. Dyn. 47: 719. http://dx.doi.org/10.1007/s00382015-2865-x.

Chen, C.T., Knutson, T., 2008. On the Verification and Comparison of Extreme Rainfall Indices from Climate Models, J. Climate. 21, 1605-1621. http://dx.doi.org/10.1175/2007JCLI1494.1.

Christensen, J.H., Carter, T.R., Rummukainen, M., Amanatidis, G., 2007. Evaluating the performance and utility of regional climate models: the prudence project. Clim. Change. 81, 1-6. http://dx.doi.org/10.1029/2002jd002782.

Das, L., Meher, J.K., Dutta, M., 2016. Construction of rainfall change scenarios over the Chilka Lagoon in India. Atmos. Res. 182, 36-45. http://dx.doi.org/10.1016/j.atmosres.2016.07.013.

Déqué, M., Rowell, D.P., Lüthi, D., Giorgi, F., Christensen, J.H., Rockel, B., van den Hurk, B.J.J.M., 2007. An intercomparison of regional climate simulations for Europe: assessing uncertainties in model projections. Clim. Change. 81(1), 53-70. http://dx.doi.org/10.1007/s10584-006-9228-x.

Déqué, M., Somot, S., Sanchez-Gomez, E., Goodess, C.M., Jacob, D., Lenderink, G., Christensen, O.B., 2012. The spread amongst ENSEMBLES regional scenarios: regional climate models, driving general circulation models and interannual variability. Clim. Dyn. 38(5), 951-964. http://dx.doi.org/10.1007/s00382-011-1053-x.

Donat, M.G., Lowry, A.L., Alexander, L.V., O'Gorman, P.A., \& Maher, N., 2017. Addendum: More extreme precipitation in the world's dry and wet regions. Nat. Clim. Chang. 7(2), 154-158. http://dx.doi.org/10.1038/NCLIMATE3160.

Endris, H.S., Omondi. P., Jain, S., Lennard, C., Hewitson, B., Chang'a, L., Awange, J.L., Dosio. A., Ketiem, P., Nikulin, G., Panitz, H.J., Büchner, M., Stordal, F., Tazalika, L., 2013. Assessment of the performance of CORDEX regional climate models in simulating east African rainfall. J. Clim. 26(21), 8453-8475. http://dx.doi.org/10.1175/JCLI-D-12-00708.1.

Haylock, M.R., Hofstra, N., Klein Tank, A.M.G., Klok, E.J., Jones, P.D., New, M., 2008. A European daily high-resolution gridded dataset of surface temperature and precipitation. J. Geophys. Res. (Atmospheres). 113, D20119. http://dx.doi.org/10.1029/2008JD10201. 
Hofstra, N., Haylock, M., New, M., Jones, P.D., 2009. Testing EOBS European high-resolution gridded data set of daily precipitation and surface temperature, J. Geophys. Res. 144, D21101. http://dx.doi.org/10.1029/2009JD011799.

Hosseinzadehtalaei, P., Tabari, H., Willems, P., 2016. Quantification of uncertainty in reference evapotranspiration climate change signals in Belgium. Hydrol. Res. http://dx.doi.org/10.2166/nh.2016.243.

Hosseinzadehtalaei, P., Tabari, H., Willems, P., 2017. Uncertainty assessment for climate change impact on intense precipitation: how many model runs do we need?. Int. J. Climatol. http://dx.doi.org/10.1002/joc.5069.

IPCC: Summary for Policymakers. Climate Change 2013.The Physical Science Basis, Contribution of Working Group I to the Fifth Assessment Report of the Intergovernmental Panel on Climate Change, In: Stocker, T. F., Qin, D., Plattner, G. K., Tignor, M., Allen, S., KBoschung, J., Nauels, A., Xia, Y., Bex, V., Midgley, P. M., (Eds.), 2013.

Jacob, D., Barring, L., Christensen, O.B., Christensen, J.H., Castro, M.D., Déqué, M., Giorgi, F., Hagemann, S., Hirschi, M., Jones, R., Kjellström, E., Lenderink, G., Rockel, B., Sanchez, E., Schär, C., Seneviratne, S.I., Somot, S., Ulden, A.V., Hurk, B.V.D., 2007. An intercomparison of regional climate models for Europe: model performance in present-day climate. Clim. Change. 81, 31-52. http://dx.doi.org/10.1007/s10584-006-9213-4.

Karandish, F., Mousavi, S.S., Tabari, H., 2016. Climate change impact on precipitation and cardinal temperatures in different climatic zones in Iran: analyzing the probable effects on cereal water-use efficiency. Stoch. Environ. Res. Risk Assess. http://dx.doi.org/10.1007/s00477-016-1355-y.

Katragkou, E., García-Díez, M., Vautard, R., Sobolowski, S., Zanis, P., Alexandri, G., Cardoso, R.M., Colette, A., Fernandez, J., Gobiet, A., Goergen, K., Karacostas, T., Knist, S., Mayer, S., Soares, P.M.M., Pytharoulis, I., Tegoulias, I., Tsikerdekis, A., Jacob, D., 2015. Regional climate hindcast simulations within EURO-CORDEX: evaluation of a WRF multi-physics ensemble. Geosci. Model Dev. 8, 603-618. http://dx.doi.org/10.5194/gmd-8-603. 
Katz, R.W., Craigmile, P.F., Guttorp, P., Haran, M., Sansó, B., Stein, M.L., 2013. Uncertainty analysis in climate change assessments. Nat. Clim. Change. 3(9), 769-771. http://dx.doi.org/doi:10.1038/nclimate1980.

Kim, B.S., Jeung, S.J., Lee, D.S., Han, W.S., 2015. Nonstationary intensity-duration-frequency curves for drainge infrastructure coping with climate change. In EGU General Assembly Conference Abstracts. 17, p. 8349.

Knutti, R., Sedláček, J., 2013. Robustness and uncertainties in the new CMIP5 climate model projections. Nat. Clim. Change. 3(4), 369-373. http://dx.doi.org/10.1038/nclimate1716.

Liew, S.C., Srivatsan, V.R, Liong, S.H., 2014. Development of Intensity-Duration-Frequency curves at ungauged sites: risk management under changing climate. Geosci. Lett. 1:8. http://dx.doi.org/10.1186/2196-4092-1-8.

Lind, P., Lindstedt, D., Kjellström, E., Jones, C., 2016. Spatial and temporal characteristics of summer precipitation over central Europe in a suite of high-resolution climate models. J. Climate. 29, 3501-3518. http://dx.doi.org/10.1175/JCLI-D-15-0463.1.

Madsen, H., Arnbjerg-Nielsen, K., Mikkelsen, P.S., 2009. Update of regional intensity-durationfrequency curves in Denmark: Tendency towards increased storm intensities. Atmos. Res. 92 (3), 343-349. http://dx.doi.org/10.1016/j.atmosres.2009.01.013.

Mailhot, A., Duchesne, S., Caya, D., Talbot, G., 2007. Assessment of future change in intensityduration-frequency (IDF) curves for Southern Quebec using the Canadian Regional Climate Model (CRCM). J. Hydrol. 347, 197-210. http://dx.doi.org/10.1016/j.jhydrol.2007.09.019.

Maraun, D., Wetterhall, F., Ireson, A.M., Chandler, R.E., Kendon, E.J., Widmann, M., Brienen, S., Rust, H.W., Sauter, T., Themeß1, M., Venema, V.K.C., Chun, K.P., Goodess, C.M., Jones, R.G., Onof, C., Vrac, M., Thiele-Eich, I., 2010. Precipitation downscaling under climate change: Recent developments to bridge the gap between dynamical models and the end user. Rev. Geophys. 48(3): RG3003. http://dx.doi.org/10.1029/2009RG000314.

Mearns, L.O., Sain, S., Leung, L.R., Bukovsky, M.S., McGinnis, S., Biner, S., Caya, D., Arritt, R.W., Gutowski, W., Takle, E., Snyder, M., Jones, R.G., Nunes, A.M.B., Tucker, S., Herzmann, D., McDaniel, L., Sloan, L., 2013. Climate change projections of the North American Regional 
Climate Change Assessment Program (NARCCAP). Clim. Change. 120(4), 965-975. http://dx.doi.org/10.1007/s10584-013-0831-3.

Peck, A., Prodanovic, P., Simonovic, S.P., 2012. Rainfall intensity duration frequency curves under climate change: City of London, Ontario, Canada. Can. Water Resour. J. 37(3), 177-189. http://dx.doi.org/10.4296/cwrj2011-935.

Pohl, B., Macron, C., Monerie, P-A., 2017. Fewer rainy days and more extreme rainfall by the end of the century in Southern Africa. Sci. Rep. 7:46466. http://dx.doi.org/10.1038/srep46466.

Prein, A.F., Gobiet, A., Truhetz, H., Keuler, K., Goergen, K., Teichmann, C., Fox Maule, C., van Meijgaard, E., Déqué, M., Nikulin, G., Vautard, R., Vautard, A., Kjellström, E., Jacob, D., 2016. Precipitation in the EURO-CORDEX $0.11^{\circ}$ and $0.44^{\circ}$ simulations: high resolution, high benefits? Clim. Dyn. 46: 383. http://dx.doi.org/10.1007/s00382-015-2589-y.

Rana, A., Foster, K., Bosshard, T., Olsson, J., Bengtsson, L., 2014. Impact of climate change on rainfall over Mumbai using Distribution-based Scaling of Global Climate Model projections. J. Hydrol. Reg. Stud. 1, 107-128. http://dx.doi.org/10.1016/j.ejrh.2014.06.005.

Refsgaard, J.C., Arnbjerg-Nielsen, K., Drews, M., Halsnæs, K., Jeppesen, E., Madsen, H., Christensen, J.H., 2013. The role of uncertainty in climate change adaptation strategies-A Danish water management example. Mitig. Adapt. Strategies Glob. Chang. 18(3), 337-359. http://dx.doi.org/10.1007/s11027-012-9366-6.

Rulfová, Z., Buishand, A., Roth, M., \& Kyselý, J., 2016. A two-component generalized extreme value distribution for precipitation frequency analysis. J. Hydrol. 534, 659-668. http://dx.doi.org/10.1016/j.jhydrol.2016.01.032.

Rummukainen, M., 2016. Added value in regional climate modeling. WIREs Clim. Change 7: 145159. http://dx.doi.org/10.1002/wcc.378.

Saeed, S., Brisson, E., Demuzere, M., Tabari, H., Willems, P., Van Lipzig, N., 2017. Multidecadal convection permitting climate simulations over Belgium: Sensitivity of future precipitation extremes. Atmos. Sci. Lett. 18:29-36. http://dx.doi.org/10.1002/as1.720. 
Sarr, M.A., Seidou, O., Tramblay, Y., El Adlouni, S., 2015. Comparison of downscaling methods for mean and extreme precipitation in Senegal. J. Hydrol. Regional Studies. 4, 369-385. http://dx.doi.org/10.1016/j.ejrh.2015.06.005.

Sunyer, M.A., Hundecha, Y., Lawrence, D., Madsen, H., Willems, P., Martinkova, M., Loukas, A., 2015. Inter-comparison of statistical downscaling methods for projection of extreme precipitation in Europe. Hydrol. Earth Syst. Sci. 19, 1827-1847. http://dx.doi.org/10.5194/hess-19-1827-2015.

Sunyer, M.A., Madsen, H., Ang, P.H., 2012. A comparison of different regional climate models and statistical downscaling methods for extreme rainfall estimation under climate change. Atmos. Res. 103, 119-128. http://dx.doi.org/10.1016/j.atmosres.2011.06.011.

Sunyer, M.A., Sørup, H.J.D., Christensen, O.B., Madsen, H., Rosbjerg, D., Mikkelsen, P.S., ArnbjergNielsen, K., 2013. On the importance of observational data properties when assessing regional climate model performance of extreme precipitation. Hydrol. Earth Syst. Sci. 17(11), 4323-4337. http://dx.doi.org/10.5194/hess-17-4323-2013.

Tabari, H., Taye, M.T., Willems, P., 2015. Water availability change in central Belgium for the late 21th century. Glob. Planet. Chang. 131, 115-123. http://dx.doi.org/10.1016/j.gloplacha.2015.05.012.

Tabari, H., De Troch, R., Giot, O., Hamdi, R., Termonia, P., Saeed, S., Brisson, E., Van Lipzig, N., Willems, P., 2016. Local impact analysis of climate change on precipitation extremes: are highresolution climate models needed for realistic simulations?. Hydrol. Earth Syst. Sci. 20:38433857. http://dx.doi.org/10.5194/hess-20-3843-2016.

Thorne, R., 2011. Uncertainty in the impacts of projected climate change on the hydrology of a subarctic environment: Liard River Basin. Hydrol. Earth Syst. Sci. 15, 1483-1492. http://dx.doi.org/10.5194/hess-15-1483-2011.

Toreti, A., Naveau, P., Zampieri, M., Schindler, A., Scoccimarro, E., Xoplaki, E., Dijkstra, H. A., Gualdi, S., Luterbacher, J., 2013. Projections of global changes in precipitation extremes from Coupled Model Intercomparison Project Phase 5 models. Geophys. Res. Lett., 40, 4887-4892. http://dx.doi.org/10.1002/grl.50940. 
Van der Linden, P., Mitchell, J.F.B., (eds.) 2009: ENSEMBLES: Climate Change and its Impacts: Summary of research and results from the ENSEMBLES project. Tech. Rep., Met Office Hadley Centre, FitzRoy Road, Exeter EX1 3PB, UK. 160pp.

Vidal, J.P., Wade, S.D., 2008. Multimodel projections of catchment-scale precipitation regime. J. Hydrol. 353, 143-158. http://dx.doi.org/10.1016/j.jhydrol.2008.02.003.

Willems, P., 2000. Compound intensity/duration/frequency-relationships of extreme precipitation for two seasons and two storm types. J. Hydrol. 233, 189-205. http://dx.doi.org/10.1016/S00221694(00)00233-X.

Willems, P., 2013. Revision of urban drainage design rules after assessment of climate change impacts on precipitation extremes at Uccle, Belgium. J. Hydrol. 496, 166-177. http://dx.doi.org/10.1016/j.jhydrol.2013.05.037.

Willems, P., Arnbjerg-Nielsen, K., Olsson, J., Nguyen, V.T.V., 2012a. Climate change impact assessment on urban rainfall extremes and urban drainage: methods and shortcomings. Atmos. Res. 103, 106-118. http://dx.doi.org/10.1016/j.atmosres.2011.04.003.

Willems, P., Olsson, J., Arnbjerg-Nielsen, K., Beecham, S., Pathirana, A., Gregersen, I.B., Madsen, H., Nguyen, V.T.V., 2012b. Impacts of Climate Change on Rainfall Extremes and Urban Drainage. IWA Publishing, London, UK.

Yan, L., Xiong, L., Liu, D., Hu, T., \& Xu, C. Y., 2017. Frequency analysis of nonstationary annual maximum flood series using the time-varying two-component mixture distributions. Hydrol. Process. 31(1), 69-89. http://dx.doi.org/10.1002/hyp.10965.

Yilmaz, A.G., Hossain, I., Perera, B.J.C., 2014. Effect of climate change and variability on extreme rainfall intensity-frequency-duration relationships: a case study of Melbourne, Hydrol. Earth Syst. Sci. 18, 4065-4076. http://dx.doi.org/10.5194/hess-18-4065-2014. 
Table 1 The EURO-CORDEX $0.11^{\circ} \mathrm{RCM} \times$ driving CMIP5 GCM matrix; labels $\mathrm{Y}$ and $\mathrm{X}$ indicate the availability of the corresponding RCM $\times$ GCM pair for the scenarios RCP 4.5 and 8.5 , respectively.

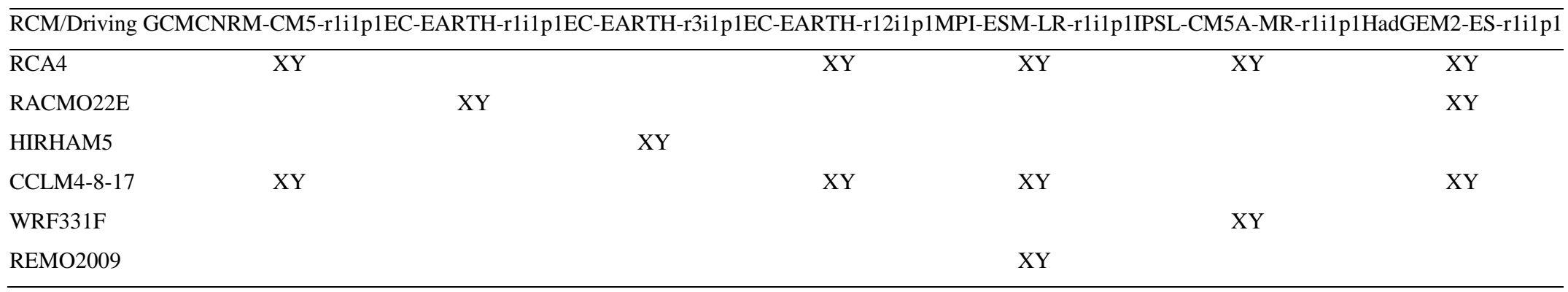

Table 2 The EURO-CORDEX $0.44^{\circ} \mathrm{RCM} \times$ driving CMIP5 GCM matrix; labels $\mathrm{Y}$ and $\mathrm{X}$ indicate the availability of the corresponding RCM $\times$ GCM pair for the scenarios RCP 4.5 and 8.5 , respectively.

\begin{tabular}{|c|c|c|c|c|c|c|c|c|c|c|c|c|}
\hline $\begin{array}{l}\text { RCM/Driving } \\
\text { GCM }\end{array}$ & $\begin{array}{l}\text { CNRM- } \\
\text { CM5- } \\
\text { r1i1p1 }\end{array}$ & $\begin{array}{c}\text { EC- } \\
\text { EARTH- } \\
\text { r1i13p1 }\end{array}$ & $\begin{array}{c}\text { EC- } \\
\text { EARTH- } \\
\text { r3ilp1 }\end{array}$ & $\begin{array}{c}\text { EC- } \\
\text { EARTH- } \\
\text { r12i1p1 }\end{array}$ & $\begin{array}{l}\text { MPI-ESM- } \\
\text { LR-r1i1p1 }\end{array}$ & $\begin{array}{c}\text { IPSL- } \\
\text { CM5A- } \\
\text { MR-r1i1p1 }\end{array}$ & $\begin{array}{l}\text { HadGEM2- } \\
\text { ES_r1i1p1 }\end{array}$ & $\begin{array}{c}\text { CanESM2- } \\
\text { r1i1p1 }\end{array}$ & $\begin{array}{l}\text { CSIRO-Mk3- } \\
\text { 6-0_r1ilp1_ }\end{array}$ & $\begin{array}{l}\text { MIROC5- } \\
\text { r1i1p1 }\end{array}$ & $\begin{array}{l}\text { NorESM1-M- } \\
\text { rlilp1 }\end{array}$ & $\begin{array}{c}\text { GFDL- } \\
\text { ESM2M- } \\
\text { rli1p1 }\end{array}$ \\
\hline$\overline{\mathrm{RCA} 4}$ & $\mathrm{XY}$ & $\mathrm{X}$ & & $\mathrm{XY}$ & $\mathrm{XY}$ & $\mathrm{XY}$ & $\mathrm{XY}$ & $\mathrm{XY}$ & $\mathrm{XY}$ & $\mathrm{XY}$ & $\mathrm{XY}$ & $\mathrm{XY}$ \\
\hline ALADIN52 & $\mathrm{Y}$ & & & & & & & & & & & \\
\hline RACMO22E & & XY & & & & & & & & & & \\
\hline HIRHAM5 & & & $X Y$ & & & & & & & & & \\
\hline CCLM4-8-17 & & & & & $\mathrm{XY}$ & & & & & & & \\
\hline WRF331F & & & & & & $\mathrm{XY}$ & & & & & & \\
\hline RegCM4-3 & & & & & & & $\mathrm{Y}$ & & & & & \\
\hline
\end{tabular}


Table 3 Precipitation intensity difference (\%) between the median of EURO-CORDEX $0.44^{\circ}$ and $0.11^{\circ}$ simulations $\left(0.44^{\circ}-0.11^{\circ}\right)$ for different return periods and durations

\begin{tabular}{lccc}
\hline Duration/Return period & 10 years & 1 year & 1 month \\
\hline 1 day & 30.30 & 24.64 & 19.22 \\
5 days & 16.31 & 18.06 & 15.13 \\
10 days & 14.76 & 25.73 & 10.60 \\
15 days & 17.36 & 17.84 & -7.20 \\
30 days & 17.30 & 14.06 & -7.21 \\
\hline
\end{tabular}



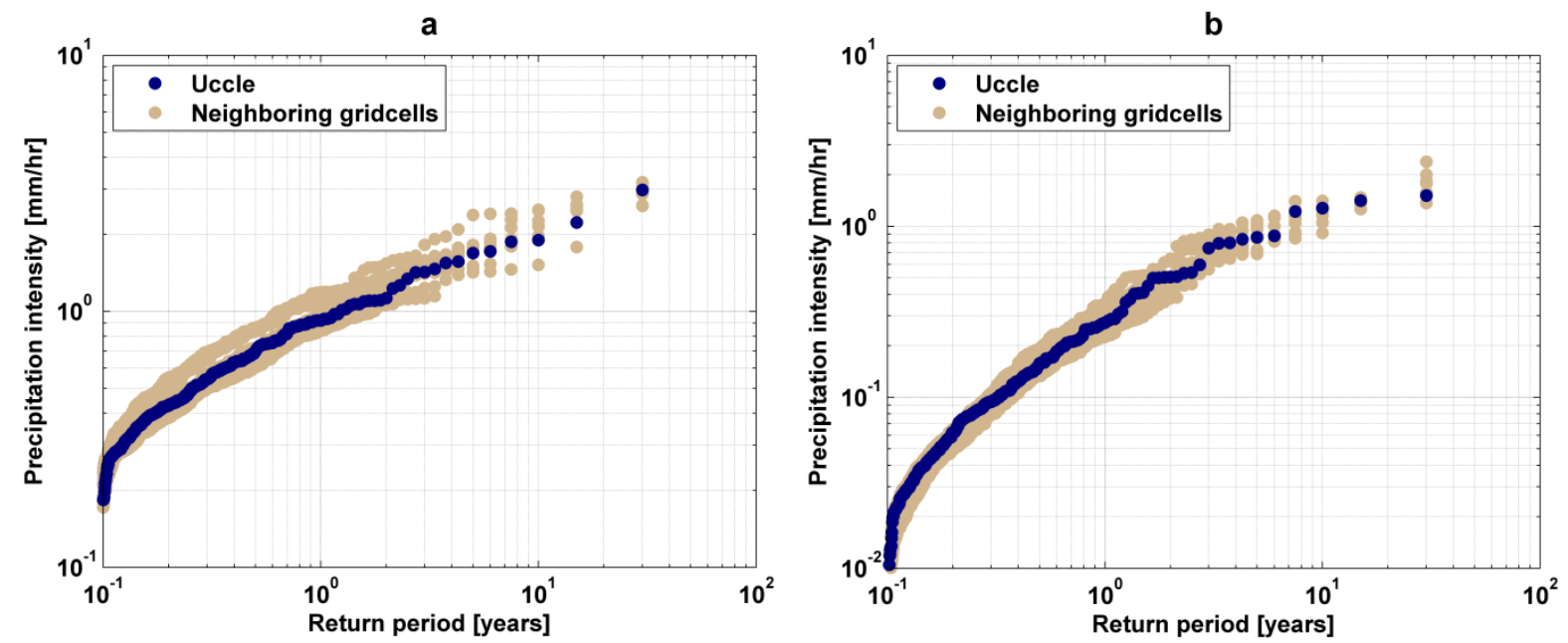

Fig. 1. Comparison of precipitation simulations over a matrix of $3 \times 3$ EURO-CORDEX model gridcells in which the central grid is the closest to Uccle station, a: $0.11^{\circ}$ simulations of RCA4 RCM nested in MPI-ESM-LR GCM, b: 0.44 simulations of REMO2009 RCM nested in MPI-ESM-LR GCM. 


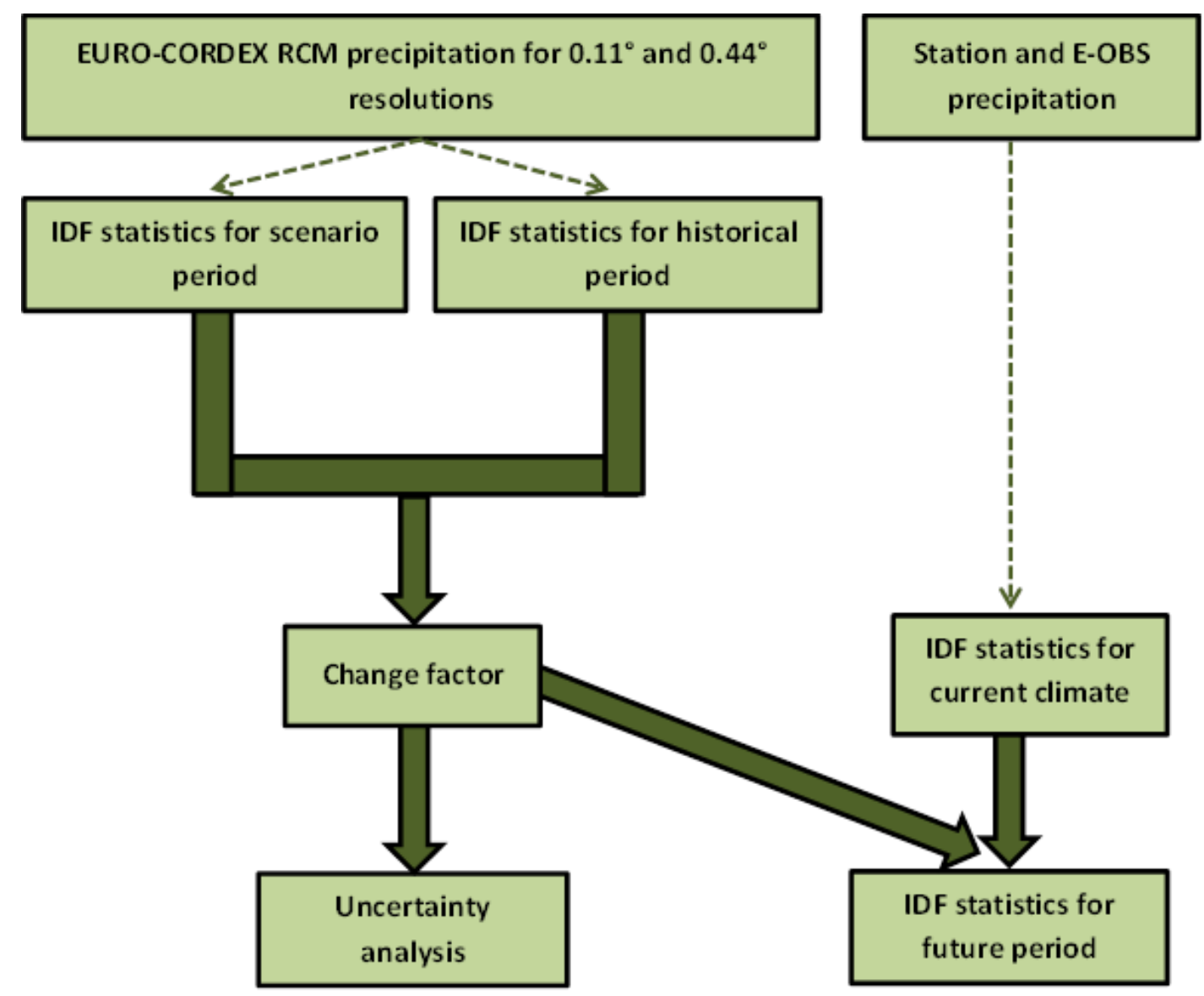

Fig. 2. Flowchart illustrating the applied methodology. 

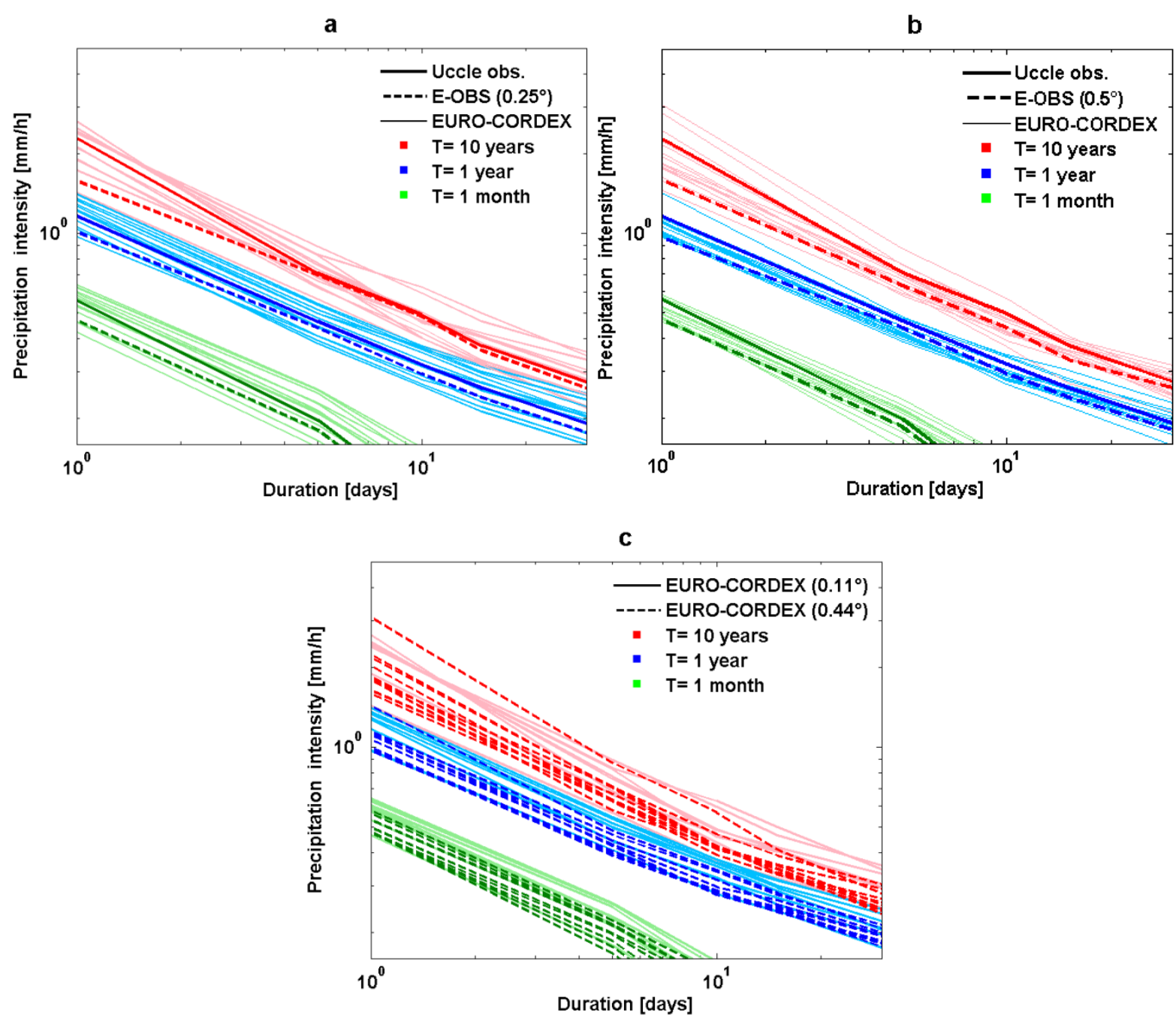

Fig. 3. Validation of the current climate IDF curves for the $0.11^{\circ}$ (a) and $0.44^{\circ}$ (b) RCMs based on the Uccle station and E-OBS observations for 10-year, 1-year and 1-month return periods and (c) comparison between the $0.11^{\circ}$ and $0.44^{\circ}$ simulations with identical combination of GCMs and RCMs (both the vertical and horizontal axes are scaled logarithmically). 

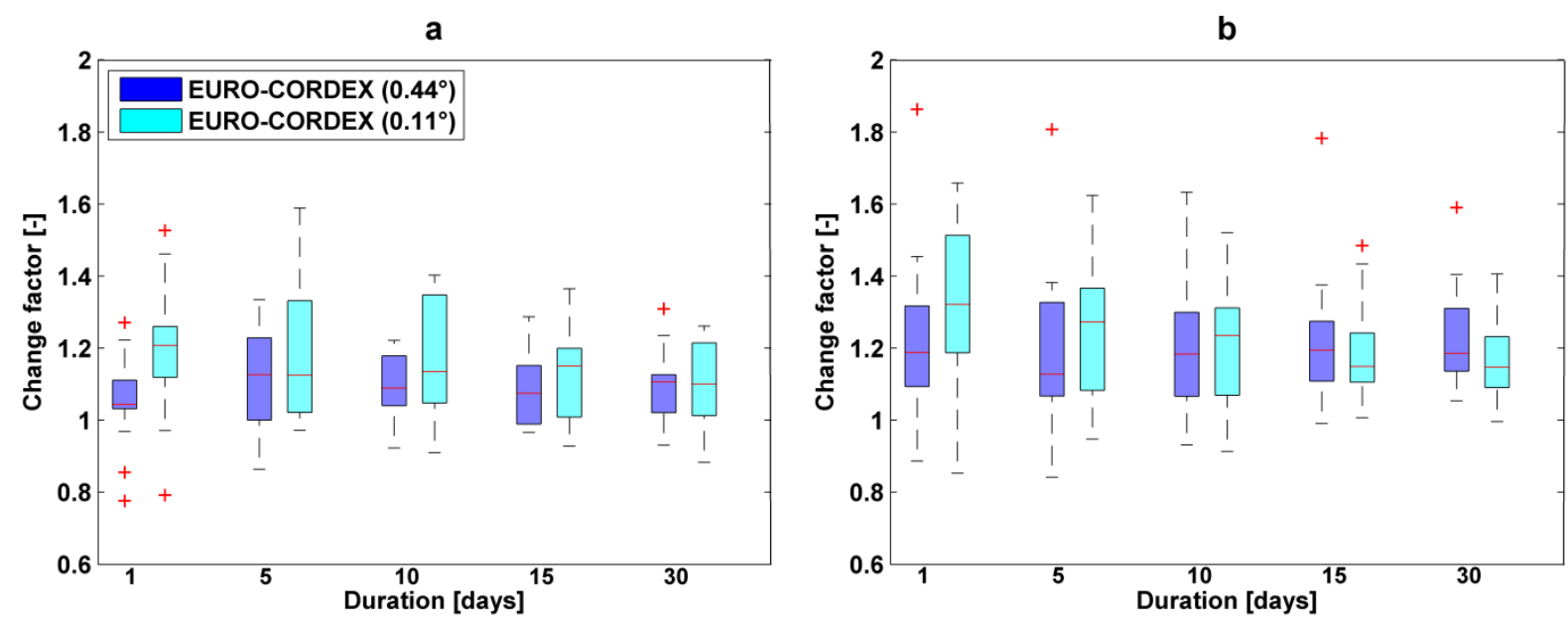

C
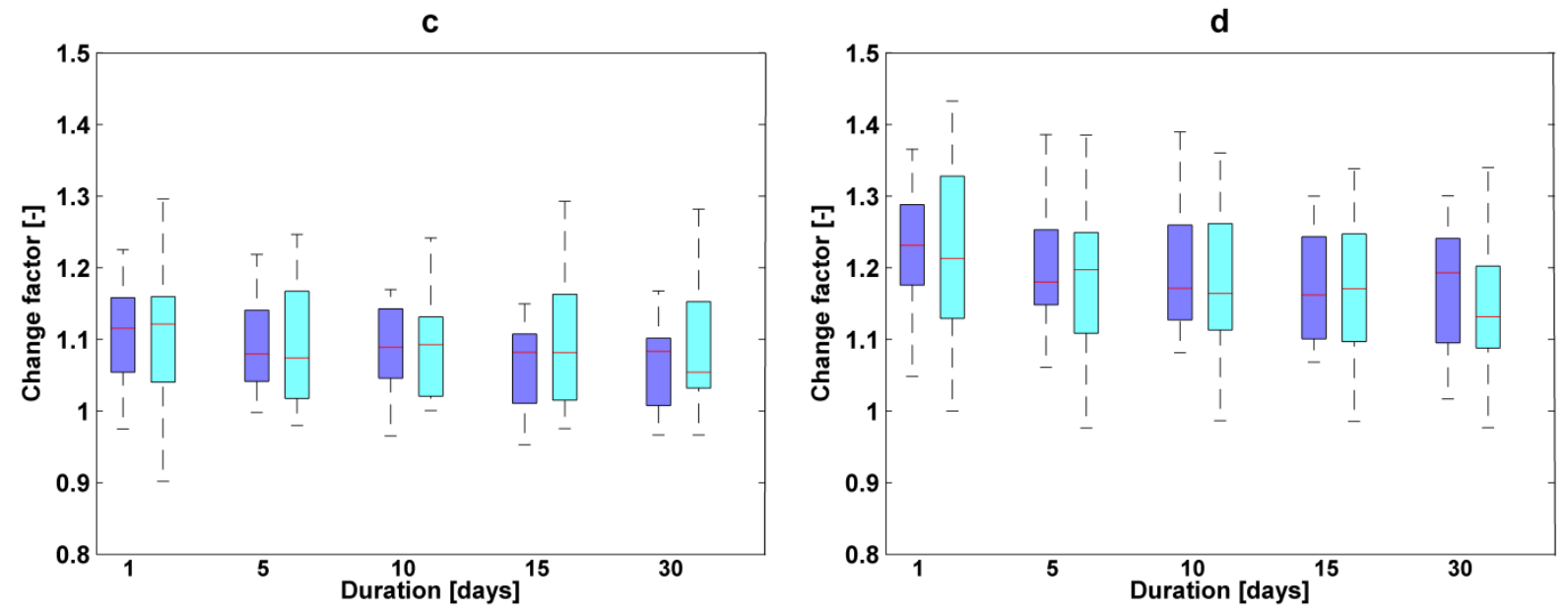

e
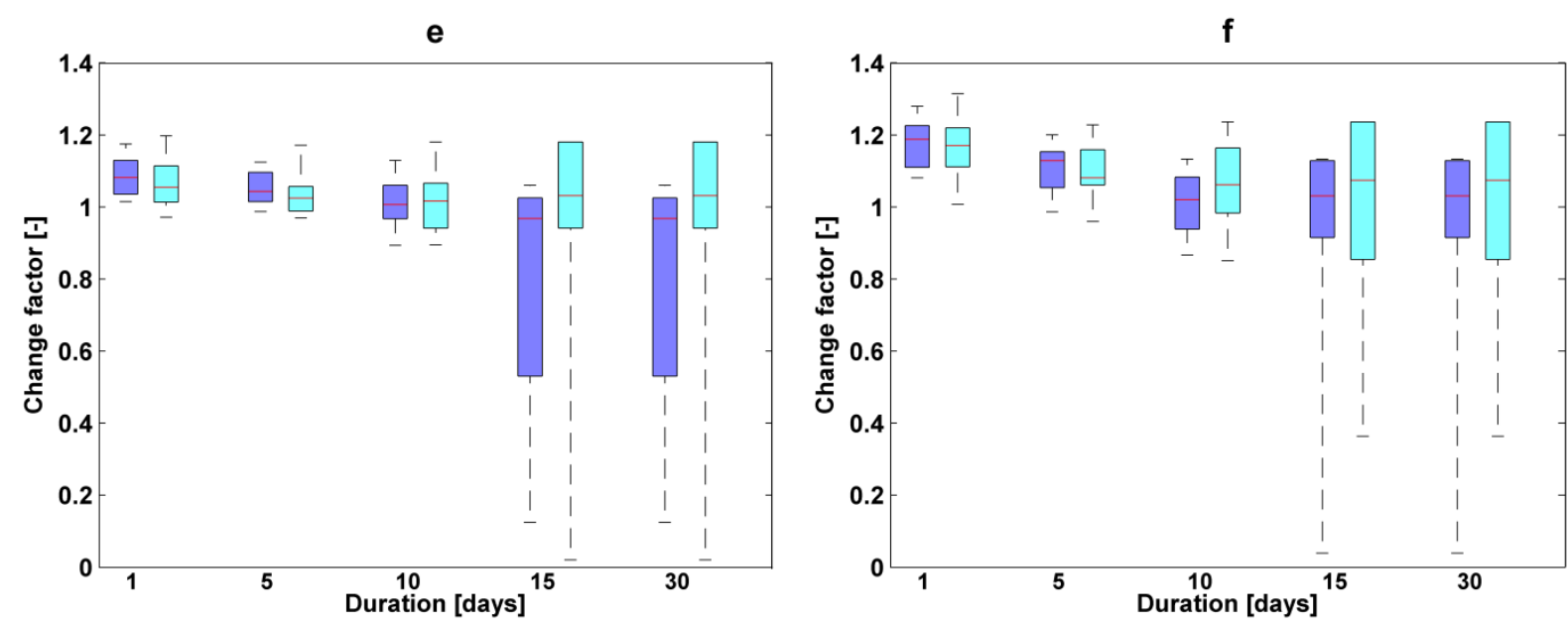

Fig. 4. Change factors of the EURO-CORDEX RCMs for extreme precipitation for 10-year $(a, b), 1$ year (c, d) and 1-month (e, f) return periods and under RCP4.5 (a, c, e) and RCP8.5 (b, d, f) scenarios (Box defines interquartile range with its top and bottom corresponding to the 25th and 75th percentiles, respectively; horizontal red line inside the box represents the median (50th percentile); whiskers represent the 5th and 95th percentiles, respectively; outliers are depicted as red crosses). 

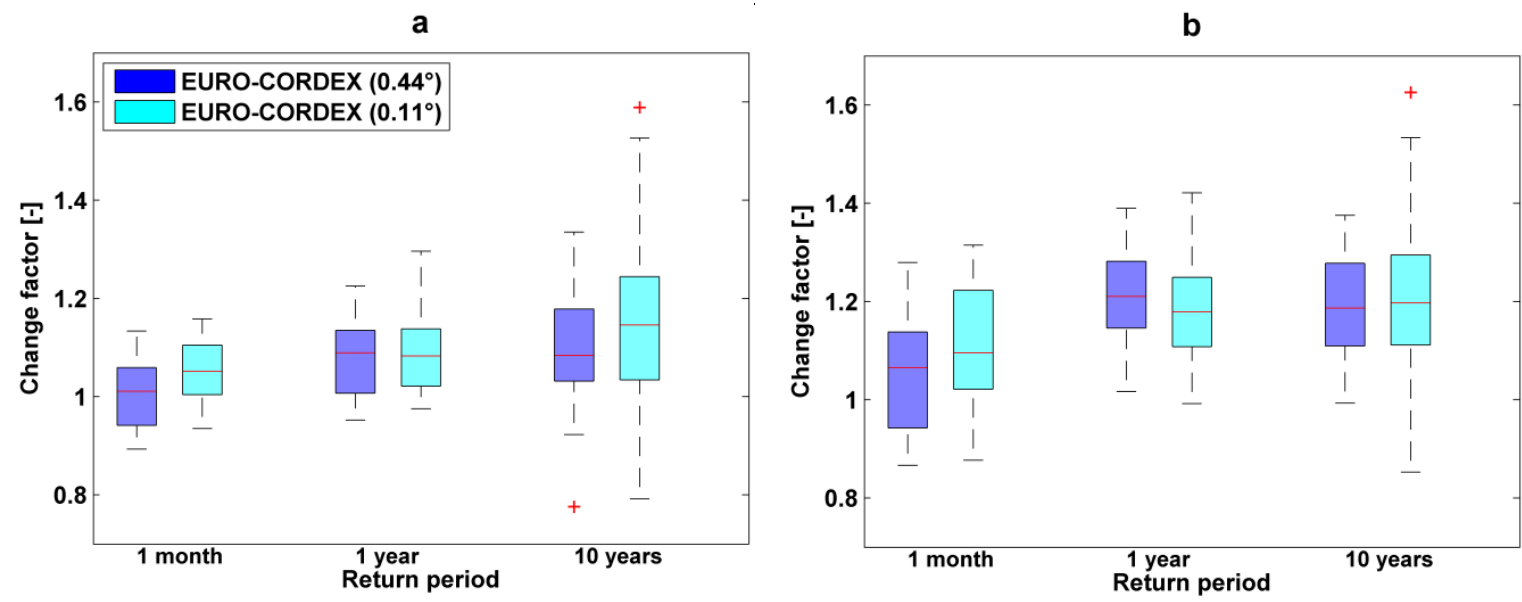

Fig. 5. Comparison between change factors of the EURO-CORDEX simulations of $0.11^{\circ}$ and $0.44^{\circ}$ resolutions with identical combination of GCMs and RCMs for extreme precipitation under RCP4.5 (a) and RCP8.5 (b) scenarios, combining all durations (Box defines interquartile range with its top and bottom corresponding to the 25 th and 75 th percentiles, respectively; horizontal red line inside the box represents the median (50th percentile); whiskers represent the 5th and 95th percentiles, respectively; outliers are depicted as red crosses). 

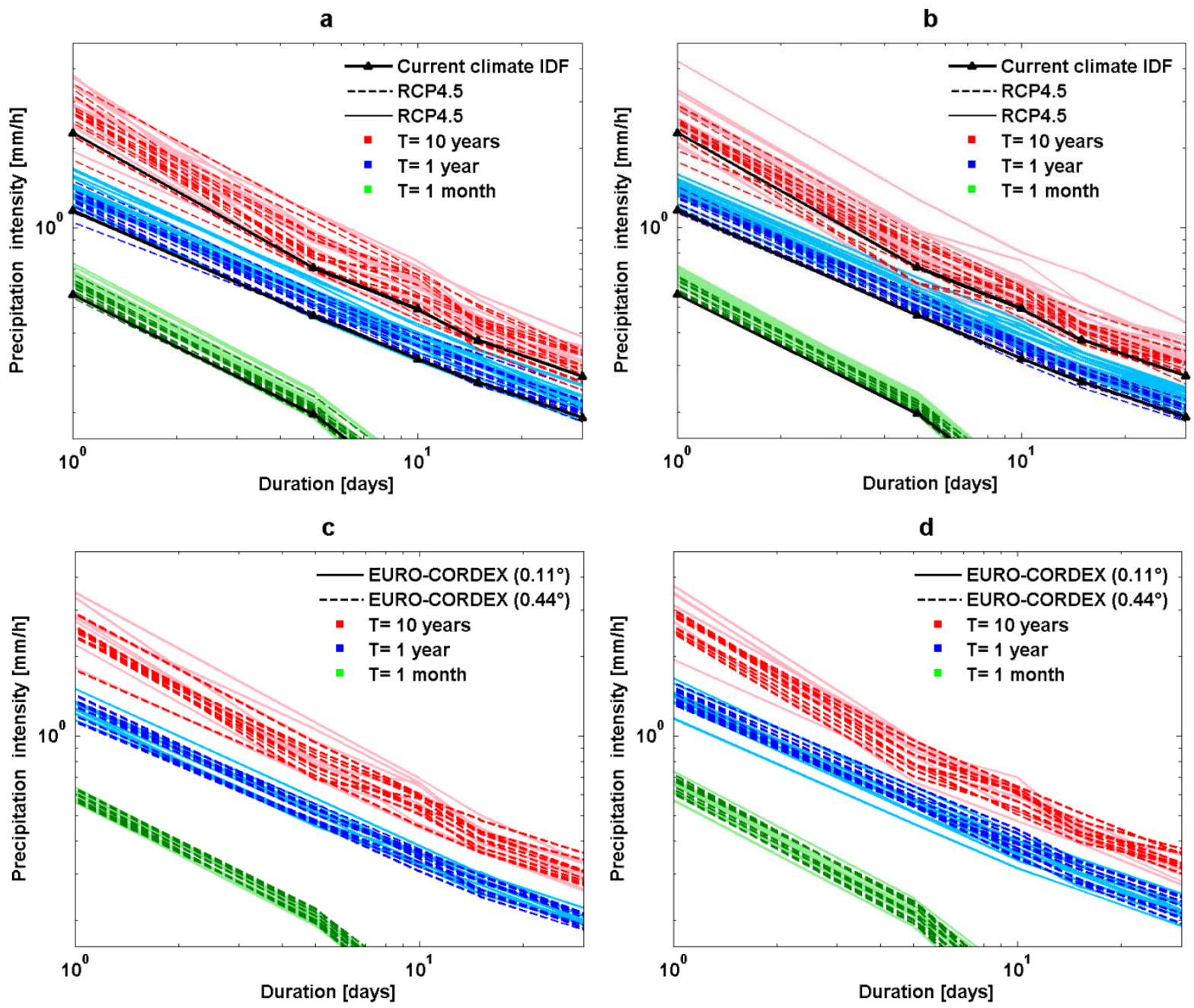

Fig. 6. Projected IDF curves for all $0.11^{\circ}$ (a) and $0.44^{\circ} \mathrm{RCM}$ (b) runs for 10-year, 1-year and 1-month return periods and $(\mathrm{c}, \mathrm{d})$ comparison between the $0.11^{\circ}$ and $0.44^{\circ}$ simulations with identical combination of GCMs and RCMs for RCP4.5 (c) and RCP8.5 (d) (both the vertical and horizontal axes are scaled logarithmically; current climate IDF curves based on the Uccle station observations are shown in black color in the sub-plots a and b). 


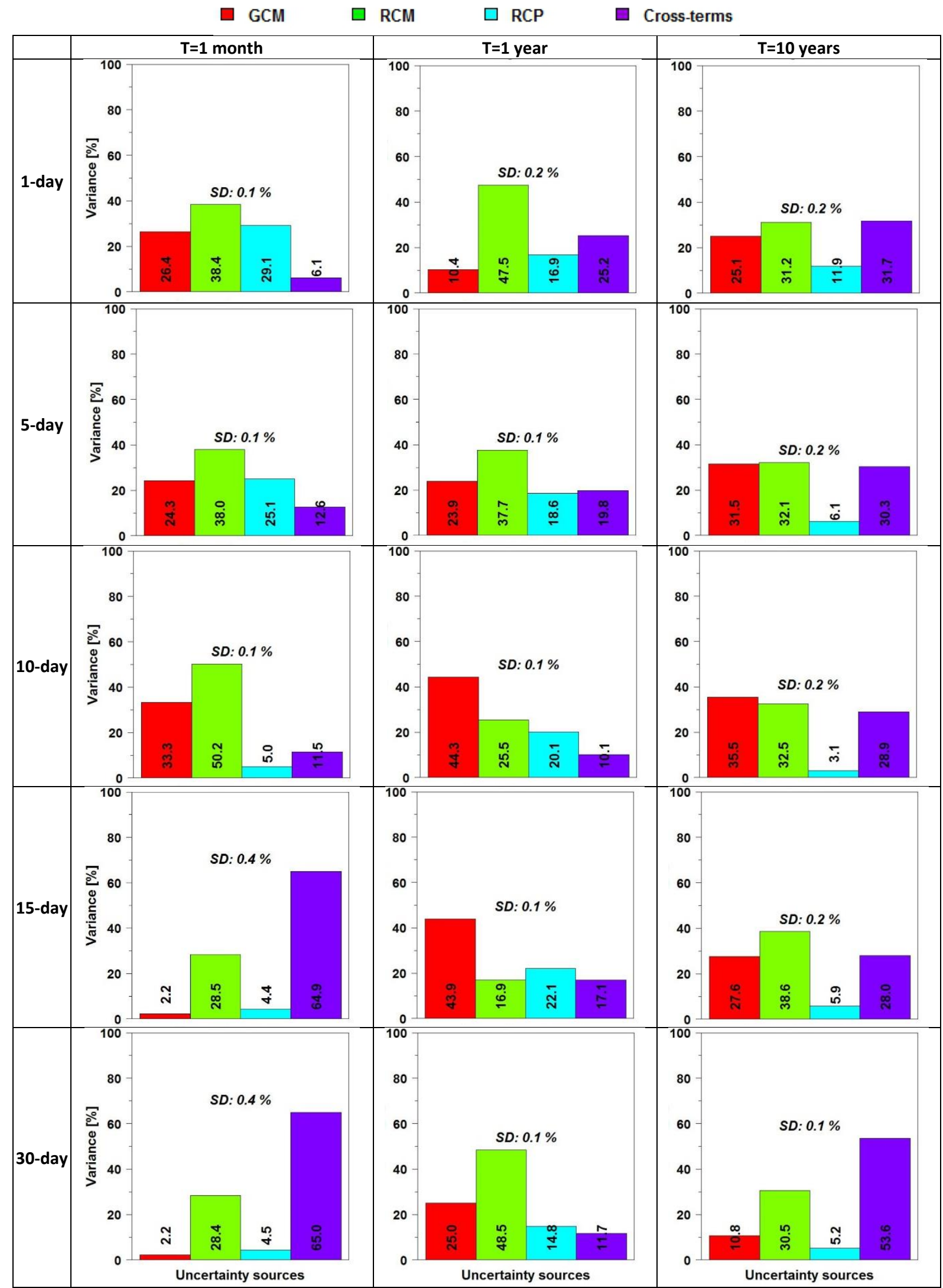

Fig. 7. Variance decomposition results for the total uncertainty in the change factors computed using the EURO-CORDEX $0.11^{\circ} \mathrm{RCMs}$ for extreme precipitation after missing data construction in $\mathrm{RCM} \times \mathrm{GCM}$ combinations: percentage of total variance explained by GCMs, RCMs, RCPs and crossterms components. 


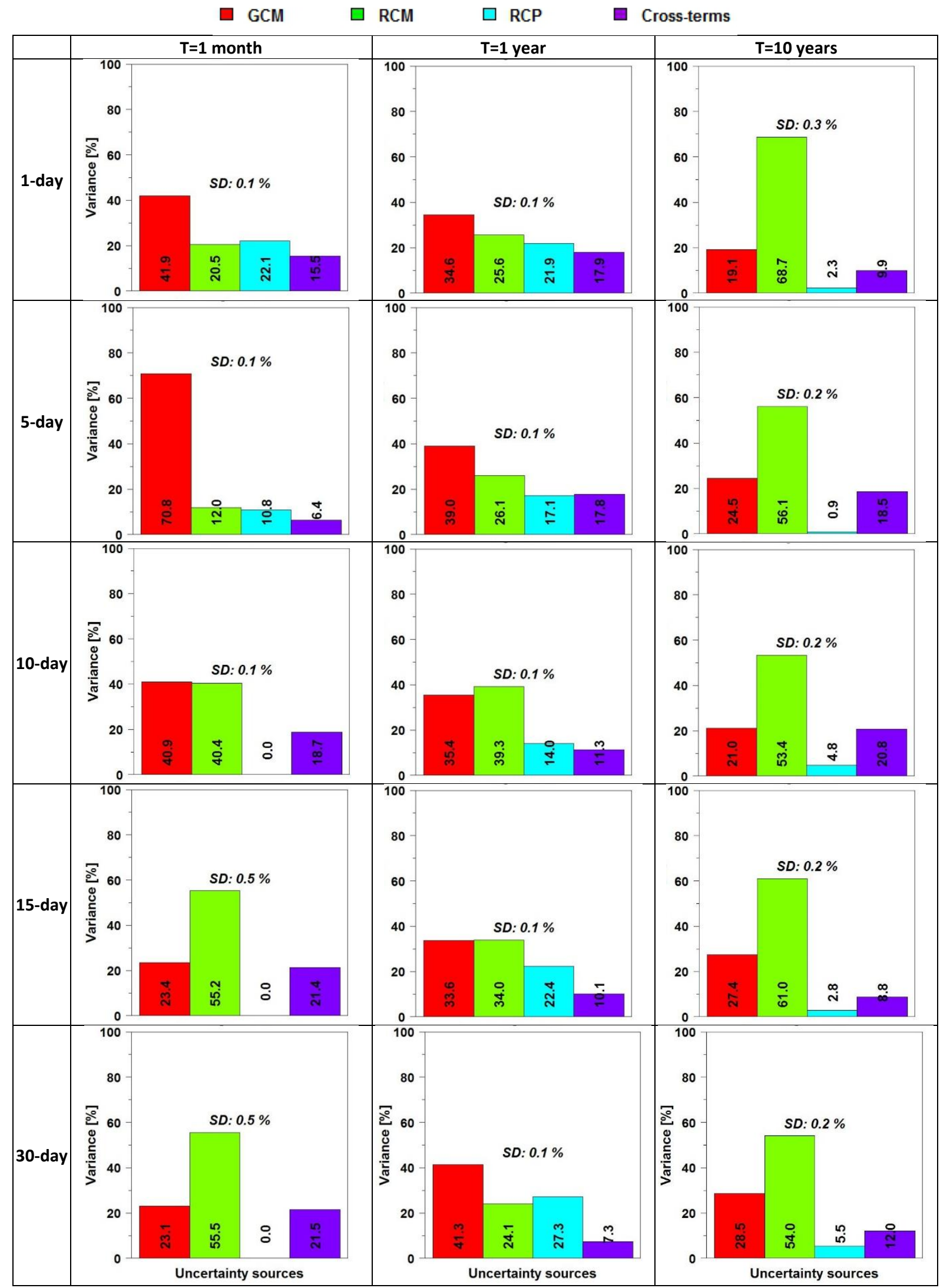

Fig. 8. Variance decomposition results for the total uncertainty in the change factors computed using the EURO-CORDEX $0.44^{\circ} \mathrm{RCMs}$ for extreme precipitation after missing data construction in $\mathrm{RCM} \times \mathrm{GCM}$ combinations: percentage of total variance explained by GCMs, RCMs, RCPs and crossterms components. 


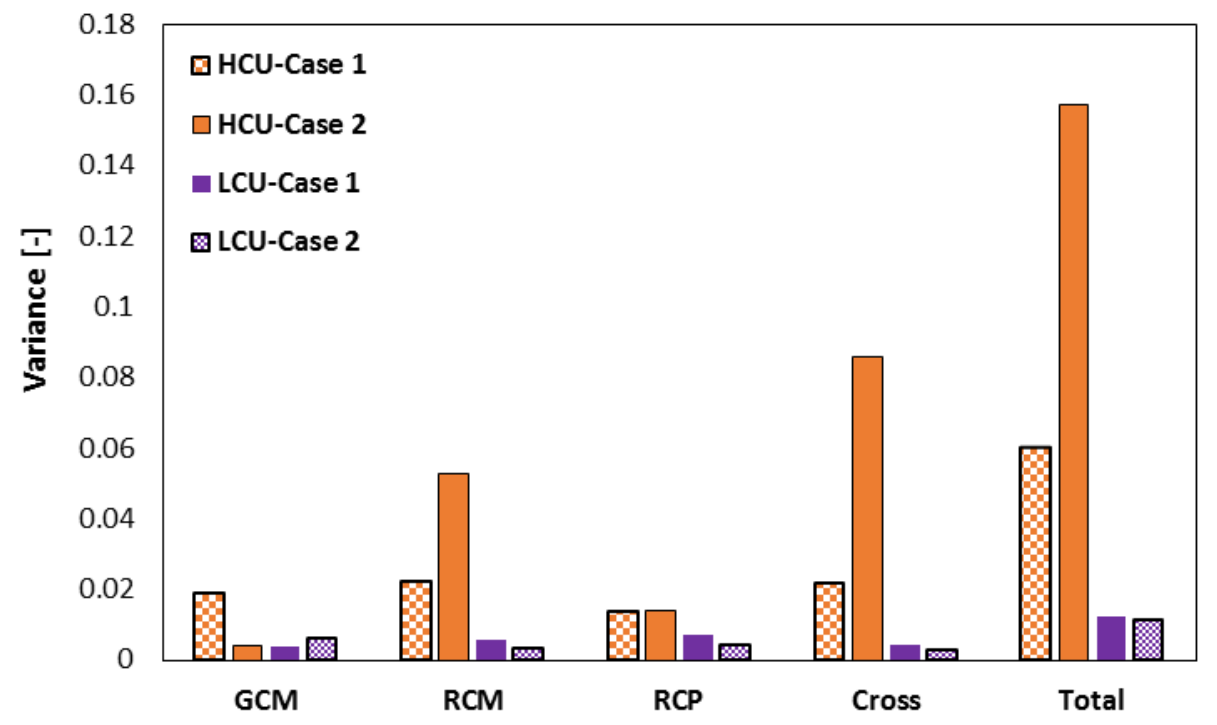

Fig. 9. Comparison of total variance contributions between two cases with high and two cases with low amount of cross term (HCU: high amount of cross uncertainty; LCU: low amount of cross uncertainty). 